\title{
The Analysis of Solution Focused Brief Counseling Contribution in Reducing First-Year Students Academic Stress Symptoms
}

\author{
Zadrian $\operatorname{Ardi}^{1}$, Daharnis ${ }^{2 *}$, Neviyarni $^{3}$, and Ifdil ${ }^{4}$
}

\author{
${ }^{1}$ Universitas Negeri Padang \\ ${ }^{2}$ Universitas Negeri Padang \\ ${ }^{3}$ Universitas Negeri Padang \\ ${ }^{4}$ Universitas Negeri Padang \\ *Corresponding author. Email: daharnis@konselor.org
}

\begin{abstract}
Various contributing factors influence the success of the learning process. Stress is one of the big problems experienced by students, especially first-year students. Students in the first year who live separately from parents tend to experience stress resulting in stressful conditions. Life changes to career decisions in the form of majors will also affect students' stress levels. Furthermore, these stress conditions are also compounded by changes in educational patterns at the educational level. An approach considered capable of being a strategic step in reducing these conditions is Solution Focused Brief Counseling (SFBC). This approach can help clients strengthen self-autonomy, strengthen thinking that focuses on solutions, formulating responsibilities, develop independence, increase self-control, and increase clients' quality of positive resources. This research aims to analyze the contribution of SFBC in reducing the academic stress conditions of first-year students. This study involved five students with high academic stress levels using the Student Academic Stress Scale (SASS). The research results show that SFBC is effective in reducing the academic stress level of first-year students.
\end{abstract}

Keywords: Academic stress, first-year student, SFBC

\section{INTRODUCTION}

Academic stress is the primary variable that contributes negatively to mental health, emotional conditions, general psychological functioning, and student learning abilities [1-3]. This pressure arises from various stressors related to academic demands. The evidence by various reports from world health associations such as the National College Health Assessment Association in the United States states that more than $58 \%$ of students in the United States find it difficult and pressured by academic demands [4]. Firstyear students from various European countries, such as Germany, Poland, and Bulgaria, experience high academic stress related to future academic demands [5, 6]. Students' perceptions about the many lecture assignments that require hard effort to complete one subject are also a determining factor for the high level of stress among students, so this significantly affects the level of student happiness and affects subjective wellbeing [6-8].

Beliefs and perceptions of academic demands also cause academic stress conditions that cause psychosomatic reactions in first-year students [9-11]. This reaction is also reinforced by the emergence of stress symptoms related to the lecture, such as Barker's findings that academic stress will increase as students approach exam times such as midterms and final exams [12, 13]. The manifestations of academic stress cause not only psychosomatic conditions but also affect impulsive behavior. This was revealed by Yeo and Lee's research results, which stated that $66.8 \%$ of students in South Korea hurt themselves in the form of pinching themselves as a form of outlet for high academic stress conditions $[14,15]$.

Other findings reveal a significant relationship between students' academic stress conditions with maladaptive behavior and low psychological quality. This is revealed from the research findings that academic stress effectively contributes $6 \%$ to student life satisfaction $[16,17]$. Another finding states that academic stress is significantly related to self-efficacy, where an increase in academic stress will reduce the level of selfefficacy [18]. The research suggests that academic stress 
can significantly predict the emergence of high anxiety among students [19].

Apart from the various findings from abroad, research on academic stress conditions also produces findings that are not much different in Indonesia. The National Commission for Child Protection and the Ministry of Health stated that from 2011 to 2015, students experiencing stress each month increased by more than $90 \%$ from previous years. The Padang City area also shows that more than $13 \%$ of students experience high levels of academic stress [20].

Moving away from the academic stress conditions that students are prone to, especially first-year students, it is necessary to minimize the impact. Academic stress is an experience inseparable from the educational process in higher education, so there should be appropriate and efficient steps in providing treatment for this condition $[21,22]$. Academic stress can be one of the main gateways to mental health problems and other practical life problems that students can experience, so it needs reasonable, progressive, effective, and efficient efforts to reduce stress symptoms. For this reason, counseling services are the right step in reducing and minimizing the academic stress conditions of first-year students [22].

Considering that academic stress conditions are a common symptom experienced by students in the form of various levels, various demographic conditions of students, and the ineffective handling and counseling services so far in universities in reaching the psychological conditions of students, it is necessary to have an approach based on methods and media, which is close to the daily lives of students [23].

To reduce academic stress conditions experienced by students, an approach considered capable of being a strategic step in reducing these conditions is Solution Focused Brief Counseling (SFBC) [24-26]. This approach can help clients strengthen self-autonomy, strengthen thinking that focuses on solutions, formulating responsibilities, develop independence, increase self-control, and increase the quality of positive resources in clients. Unlike other traditional approaches (which also focus on solutions), SFBC has the premise that the details about a problem are not overly questioned and are not significant in finding solutions to problems $[27,28]$. This approach also focuses on problems that need quick handling but at a less severe level, previous client experiences that are successful in problem-solving, and focuses on the present and the future, not on the past $[29,30]$.

Furthermore, this approach has five basic principles, namely (1) the counseling approach is directed at constructive change, (2) in finding solutions, there is always an exception process if the problem does not exist to lead the client to find a solution gradually. To problems, (3) small and positive changes bring more significant and positive changes, (4) all clients can solve their problems by exposing, detailing, and replicating previous successes, (5) counseling objectives need to be stated in favorable, measurable terms, and active voice [31]. Besides, this approach is also suitable for various problems related to maladaptive behavior, including those related to conditions of anxiety, stress, and depression.

This study focuses on finding the extent the Solution Focused Brief Counseling approach can reduce the level of academic stress experienced by students. This study also focused on first-year students as the students with the highest levels of academic stress symptoms with more symptom-forming variables.

\section{METHODS}

\subsection{Participant}

The research sample was taken after mapping the academic stress conditions experienced by students so that the sample conditions were known after the distribution of assessments related to student academic stress conditions. After measuring 3524 students using the Student Academic Stress Scale (SASS) in the Sumatra Indonesia area, it was found that more than $15 \%$ students had high levels of academic stress. From the measurement results, five people were selected to follow the counseling process using the Solution Focused Brief Counseling (SFBC) approach.

\subsection{Measurement}

Measurement of student academic stress conditions was carried out using the Student Academic Stress Scale (SASS) instrument, a development of the Educational Stress Scale for College-Student (ESSC) developed by Sun, Dunne, Hou \& Xu [32]. After testing the instrument, the validity value was obtained based on a logit scale using Rasch analysis as in Table 1.

The results of the validation of the instrument show a reasonably good separation value, which can differentiate between one individual and another. Besides that, the item value also shows a fair value of reliability and validity.

\subsection{Data Analysis}

Hypothesis testing in this study was carried out by looking at the characteristics of the data. Research data has the following data characteristics. (1) in pairs (pretest-posttest), (2) small subjects who are assumed to be not normally distributed, (3) using experimental research or treatment. Based on the data's characteristics, paying attention to the small amount of data (less than 30) and considering the initial score (pretest), the data analysis technique used is nonparametric statistics;

Table 1. Instrument reliability conditions, mean and item separation (logit scale)

\begin{tabular}{|c|c|c|c|c|}
\hline & $\begin{array}{c}\text { Mean } \\
\text { (SD) }\end{array}$ & Separation & Reliability & $\begin{array}{c}\text { Alpha } \\
\text { Cronba } \\
\text { ch }\end{array}$ \\
\hline Person & $\begin{array}{c}-0.53 \\
(0.65)\end{array}$ & 1.94 & 0.89 & \multirow{2}{*}{0.92} \\
\cline { 1 - 3 } Item & $\begin{array}{c}0.00 \\
(2.06)\end{array}$ & 14.48 & 1.00 & \\
\hline
\end{tabular}

namely, Wilcoxon Signed Ranks Test and Kolmogorov Smirnov 2 Independent Samples. 


\section{RESULT AND DISCUSSION}

Based on the research findings, it is known that in general, students experience moderate levels of stress, this indicates that students feel the burdens and pressures in the lecture process and campus life to be quite disturbing even though they do not have a significant effect in various activities or daily activities.

Even so, there are five students experience high levels of academic stress. This achievement indicated that some of these students' pressure and academic burden hampered their daily activities, both in self-development and other activities. High academic stress levels are also a reference for improving all elements in the student learning process.

Students' high academic stress level is also a reference in this study to provide intervention in the form of counseling using the Solution Focused Brief Counseling (SFBC) approach. Using these approaches will be known which approach effectively reduces student academic stress levels so that the implementation of counseling interventions becomes more effective and efficient.

Counseling interventions for subjects who have high academic stress levels are given within a week after the assessment through the instrument. The experimental subjects were taken based on respondents who had high academic stress levels as many as five subjects.

The provision of individual counseling interventions with the SFBC approach was carried out for two weeks, with each subject given a minimum of two counseling sessions. Before the intervention, the subject was informed that the intervention would be given with the SFBC approach.

Based on a series of counseling interventions with the SFBC approach, it is known through Graph 1 that there is a decrease in the level of academic stress of students from before being given treatment. In graph 1, it can be seen that the five times SFBC treatment was given shows a decrease in the level of academic stress experienced by students. In the first treatment, all research subjects had high academic stress levels (above a score of 136). There was a decrease in some subjects in the second treatment, but all subjects showed changes after the second treatment was given. This indicates that there is a contribution from the SFBC approach to reducing academic stress levels.

200

150

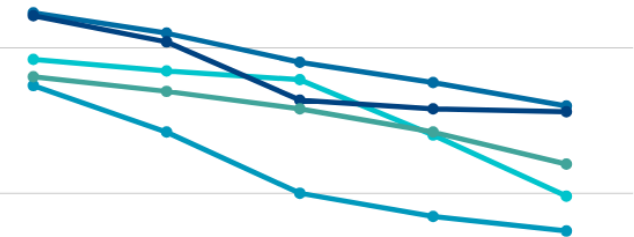

50
To prove SFBC treatment's contribution to reducing levels of academic stress, a sign test was carried out using the Wilcoxon Signed Ranks Test as in Table 2.

Table 2. Analysis of Wilcoxon Signed Ranks Test Pretest and Posttest of Academic Stress

\begin{tabular}{|c|c|c|c|c|}
\hline Analysis & $\mathbf{N}$ & $\begin{array}{c}\mathbf{Z} \\
\text { coefficient }\end{array}$ & Asym.Sig & t-test \\
\cline { 1 - 4 } Pretest & \multirow{2}{*}{5} & $3.064 \mathrm{~b}$ & .002 & .005 \\
\hline Posttest & 5 &
\end{tabular}

Based on the test results in Table 2, it is known that there is a significant difference between the pre-test and post-test results of the counseling treatment with the SFBC approach. The test also proved a significant change in the student's academic stress level after being given the treatment, where the post-test results showed that the students experienced a decrease in academic stress levels after the counseling intervention was conducted. This significant reduction is also illustrated through Graph 1 and strengthened by analysis testing through Table 2 . The $\mathrm{Z}$ coefficient value also shows the value of a decrease in students' academic stress level with a gain of -3.064. This finding can be interpreted as a decrease in academic stress levels.

This finding is following the basic concept of counseling intervention with the Solution Focused Brief Counseling (SFBC) approach, which is an approach that emphasizes reducing the focus on the client's past problems but instead emphasizes a focus on what can work on the client (such as success and solutions) [28, 33, 34]. Furthermore, exceptions in the client's life during which the problem did not occur. This approach argues that everyone has strengths, resources, and problemsolving skills, which are the skills that the client will bring during the counseling process.

\section{CONCLUSION}

Based on the research findings, it is known that in general, students experience moderate levels of stress, this indicates that students feel the burden and pressure in the lecture process and campus life to be quite disturbing, although it does not have a significant effect in various activities or daily activities. There are still some students who have high levels of academic stress, so that they become targets of counseling interventions using the SFBC approach. With five treatments using SFBC, there was a significant reduction in academic stress levels. The Solution Focused Brief Counseling (SFBC) approach contributed to reducing students' academic stress in the experimental group.

\section{REFERENCES}

[1] E. T. Barker, A. L. Howard, R. VillemaireKrajden, and N. L. Galambos, "The Rise and Fall of Depressive Symptoms and Academic Stress in Two Samples of University Students," Journal of Youth and Adolescence, vol. 47, no. 6, pp. 12521266, 2018, doi: 10.1007/s10964-018-0822-9.
0
T3

$\mathrm{T} 4$ 
[2] H. K. Allen, A. L. Barrall, K. B. Vincent, and A. M. Arria, "Stress and Burnout Among Graduate Students: Moderation by Sleep Duration and Quality," International Journal of Behavioral Medicine, Article 2020, doi: 10.1007/s12529020-09867-8.

[3] S. A. Benton, M. Heesacker, S. J. Snowden, and G. Lee, "Therapist-assisted, online (TAO) intervention for anxiety in college students: TAO outperformed treatment as usual," Professional Psychology: Research and Practice, vol. 47, no. 5, p. 363, 2016.

[4] L. M. Farrer et al., "Development of the Uni Virtual Clinic: an online programme for improving the mental health of university students," British Journal of Guidance \& Counselling, pp. 1-14, 2020.

[5] A. K. Arnekrans et al., "College Students' Experiences of Childhood Developmental Traumatic Stress: Resilience, First-Year Academic Performance, and Substance Use," Journal of College Counseling, Article vol. 21, no. 1, pp. 2-14, 2018, doi: 10.1002/jocc. 12083.

[6] D. K. Cheung, D. K. Y. Tam, M. H. Tsang, D. L. W. Zhang, and D. S. W. Lit, "Depression, anxiety and stress in different subgroups of first-year university students from 4-year cohort data," Journal of Affective Disorders, Article vol. 274, pp. 305-314, 2020, doi: 10.1016/j.jad.2020.05.041.

[7] Z. Ardi, "An analysis of education principle implementation in an online counseling approach: a preliminary study based on analysis using the Rasch model," COUNS-EDU: The International Journal of Counseling and Education, vol. 4, no. 2, pp. 59-68, 2019.

[8] L. A. House, C. Neal, and J. Kolb, "Supporting the Mental Health Needs of First Generation College Students," Journal of College Student Psychotherapy, vol. 34, no. 2, pp. 157-167, 2020.

[9] G. Sakitri, "The relationship among student stress, Type A personality, and academic performance in a business school in Indonesia," Journal of Education for Business, vol. 95, no. 3, pp. 169179, 2020.

[10] H. K. Rustam and F. Tentama, "Creating Academic Stress Scale And The Application For Students: Validity And Reliability Test In Psychometrics," International Journal of Scientific \& Technology Research, vol. 9, no. 1, pp. 661-667, 2020.

[11] G. Boyraz, Y. Zhu, and J. B. Waits, "Avoidance coping and academic locus of control as mediators of the relationship between posttraumatic stress and academic achievement among first-year college students," Anxiety, Stress and Coping, Article vol. 32, no. 5, pp. 545-558, 2019, doi: 10.1080/10615806.2019.1638681.

[12] A. Rezaei and E. Mousanezhad Jeddi, "Relationship between wisdom, perceived control of internal states, perceived stress, social intelligence, information processing styles and life satisfaction among college students," (in English), Current Psychology, Article vol. 39, no. 3, pp. 927-933, 2020, doi: 10.1007/s12144-0189804-z.

[13] Wisnalmawati, C. Huda, I. K. Ningrum, and K. Lukiyanto, "Web application facilities can build academic atmospere promotion student satisfaction in college," International Journal of Scientific and Technology Research, Article vol. 8, no. 12, pp. 1196-1199, 2019. [Online]. Available:

https://www.scopus.com/inward/record.uri?eid= 2-s2.0-

$\underline{85077608249 \& \text { partnerID }=40 \& \text { md5 }=\text { ed } 9293 \mathrm{fa} 68}$ 0cb103d8e9303b99e1b269.

[14] C. Yoo, "Longitudinal Relationship between Academic Stress and Bonding Social Capital: Risk and Protective Roles of 'Bonding Social Capital and Academic Stress' According to Specific Situations in South Korean Adolescents," Child Indicators Research, vol. 11, no. 1, pp. 245 261, 2018, doi: 10.1007/s12187-016-9433-8.

[15] Y. Kim, K. Kwak, and S. Lee, "Does Optimism Moderate Parental Achievement Pressure and Academic Stress in Korean Children?," Current Psychology, vol. 35, no. 1, pp. 39-43, 2016, doi: 10.1007/s12144-015-9355-5.

[16] J. Zhang and Y. Zheng, "How do academic stress and leisure activities influence college students' emotional well-being? A daily diary investigation," Journal of Adolescence, vol. 60, pp. 114-118, 2017, doi: 10.1016/j.adolescence.2017.08.003.

[17] L. Zhang, S. Qin, Z. Yao, K. Zhang, and J. Wu, "Long-term academic stress enhances early processing of facial expressions," International Journal of Psychophysiology, vol. 109, pp. 138146, 2016, doi: 10.1016/j.ijpsycho.2016.08.010.

[18] M. A. Karaman, E. Lerma, J. C. Vela, and J. C. Watson, "Predictors of academic stress among college students," Journal of College Counseling, vol. 22, no. 1, pp. 41-55, 2019.

[19] Y.-W. Yan, R.-M. Lin, Y.-K. Su, and M.-Y. Liu, "The relationship between adolescent academic stress and sleep quality: A multiple mediation model," Social Behavior and Personality: an international journal, vol. 46, no. 1, pp. 63-77, 2018, doi: 10.2224/sbp.6530.

[20] T. Taufik, I. Ifdil, and Z. Ardi, "Kondisi Stres Akademik Siswa SMA Negeri di Kota Padang," Jurnal Konseling dan Pendidikan, vol. 1, no. 2, pp. 143-150, 2013. [Online]. Available: http://jurnal.konselingindonesia.com.

[21] Z. Ardi, M. R. M. Putra, and I. Ifdil, "Ethics And Legal Issues In Online Counseling Services: Counseling Principles Analysis," Jurnal Psikologi Pendidikan dan Konseling: Jurnal Kajian 
Psikologi Pendidikan dan Bimbingan Konseling, pp. 15-22, 2017.

[22] Z. Ardi, I. Sukmawati, I. Ifdil, A. Afdal, I. Rangka, and K. Suranata, "Exploring the acceptability of internet-based mental health mobile app services using network psychometrics analysis," in Journal of Physics: Conference Series, 2018, vol. 1114, no. 1: IOP Publishing, p. 012106.

[23] Z. Ardi, Neviyarni, and Daharnis, "Konselo app: The future of distance counselling and therapy applications based on android technology," (in English), International Journal of Innovation, Creativity and Change, Article vol. 5, no. 6, pp. 231-244, 2019. [Online]. Available: https://www.scopus.com/inward/record.uri?eid= 2-s2.0-

$\underline{85084436048 \& \text { partnerID }=40 \& \mathrm{md} 5=\mathrm{fa} 9 \mathrm{c} 4 \mathrm{~d} 31 \mathrm{~b} 0}$ 195e977e60383f7350523c.

[24] X. Zhang, X. Shi, S. Xu, J. Qiu, O. Turel, and Q. $\mathrm{He}$, "The Effect of Solution-Focused Group Counseling Intervention on College Students' Internet Addiction: A Pilot Study," International Journal of Environmental Research and Public Health, vol. 17, no. 7, p. 2519, 2020.

[25] W. S. Hsu, H. J. Lin, S. T. M. Sun, and H. J. Chen, "The Training Effects of Solution-Focused Brief Counseling on Telephone-Counseling Volunteers in Taiwan," Journal of Family Psychotherapy, vol. 28, no. 4, pp. 285-302, 2017, doi: 10.1080/08975353.2017.1297066.

[26] C. Franklin, A. Zhang, A. Froerer, and S. Johnson, "Solution Focused Brief Therapy: A Systematic Review and Meta-Summary of Process Research," Journal of Marital and Family Therapy, vol. 43, no. 1, pp. 16-30, 2017, doi: 10.1111/jmft.12193.

[27] V. Ooi and E. L. Chan, "Family Offices, Private Trust Companies and Trust Integrity Issues: Problems and Solutions," Asian Wealth and the Global Context, Richard Nolan, Tang Hang Wu and Yip Man (eds)(2020)(CUP)(Forthcoming), 2020.

[28] J. K. Novella, K.-M. Ng, and J. Samuolis, "A comparison of online and in-person counseling outcomes using solution-focused brief therapy for college students with anxiety," Journal of American College Health, pp. 1-8, 2020.

[29] N. Javid, A. Ahmadi, M. Mirzaei, and M. Atghaei, "Effectiveness of Solution-Focused Group Counseling on the Mental Health of Midwifery Students," Revista Brasileira de Ginecologia e Obstetrícia/RBGO Gynecology and Obstetrics, vol. 41, no. 08, pp. 500-507, 2019.

[30] C. Franklin, A. Zhang, A. Froerer, and S. Johnson, "Solution Focused Brief Therapy: A Systematic

Review and Meta - Summary of Process Research," Journal of marital and family therapy, vol. 43, no. 1, pp. 16-30, 2017.
[31] J. T. Guterman, Mastering the art of solutionfocused counseling. Wiley Online Library, 2014.

[32] J. Sun, M. P. Dunne, X.-Y. Hou, and A.-q. Xu, "Educational stress scale for adolescents: development, validity, and reliability with Chinese students," Journal of Psychoeducational Assessment, vol. 29, no. 6, pp. 534-546, 2011.

[33] S. Mache, M. Bernburg, L. Baresi, and D. A. Groneberg, "Evaluation of self-care skills training and solution-focused counselling for health professionals in psychiatric medicine: a pilot study," International Journal of Psychiatry in Clinical Practice, vol. 20, no. 4, pp. 239-244, 2016, doi: 10.1080/13651501.2016.1207085.

[34] S. De Shazer and Y. Dolan, More than miracles: The state of the art of solution-focused brief therapy. Routledge, 2012. 